\title{
Open Banking and Digital Disruptions: Would Retail Bankers be Losing their Jobs?
}

\author{
Maruf Gbadebo Salimon* \\ Department of Marketing, Universiti Utara Malaysia, Malaysia \\ Submission: September 11, 2019; Published: October 03, 2019 \\ *Corresponding author: Maruf Gbadebo Salimon, Department of Marketing, Universiti Utara Malaysia, Malaysia
}

Keywords: Banking; Digital disruptions; Retail bnkers

\section{Opinion}

In 1990, Bill Gates argued that banking is necessary, but banks are not. This statement that was made almost three decades ago seems to be the reality of recent events in the landscape of banking and payment industry. The reality is almost done on retail bankers especially that the payment system is becoming open and highly liberated. In Europe, specifically, banks are faced with enormous threats due to the rapid and widespread changes which are ushered in by the digital disruptions that might take away the jobs of the traditional bankers.

What are the changes that are involved? Accenture recently identified several changes blowing heavily in the landscape of payment system and of which are threatening the incumbent banks' revenue and customer ownership. First, the demands from customers are seriously evolving due to large volume of transactions being performed on mobile devices, as these users are equally asking for personalized services, seamless and realtime payment experiences. Second, the dawn of tough competition is here as FinTech organizations and other traditional financial services providers are forming synergy to offer unconventional services within the expanded payments ecosystem. Third, the regulatory initiatives such as revised Payment Services Directives (PSD2) is crucially encouraging innovation and competition in the industry. Finally, the recent uprising in technology in the realm of instant payment infrastructures, mobile authentication, blockchain, and 'Internet of Things (IoT) has brought about digitized end-to-end new methods of system of payment.

Given the above changes, what should the traditional bankers do to retain their jobs? It is not just about bankers' job but about creating an effective payment ecosystem that would ensure that the landscape of this industry is secured and competitive. For instance, as customers are demanding for flexible and personalized banking, the challenge thrown at the existing retail bankers is to embrace open banking system which ensures that their customers' data (with the consent of the customers) are shared with newly regulated and existing other secured companies (FinTech Companies and others) for the purpose of enjoying super-fast payment methods and innovative banking products.

PSD2 is a revised version of initial Payment Services Directive and becomes effective January 2018 across the European Union and the European Economic Area. The PSD2 is aiding the open banking system as it is opening the door virtually to any organization that has interest in eating a bank's lunch. The basic of PSD2 is that it enables customers of banks to use third-party to manage their finances. For instance, while you still maintain your account with your preferred bank, you may be using Google or Facebook to settle your bills, transfer money to your colleagues and even analyse your spending. Impliedly, the banks would not only be competing against other banks but all other licenced organizations to offer financial services. The open banking system would worth $£ 8.5$ bn pounds revenue for the banking and payment industry by year 2020 .

The uprising in technology is another disruption that needs to be coped with. Blockchain for instance, has come to stay and would be posing a new challenge to the bankers. In fact, the blockchain is transforming everything from payments transactions to how money is raised in the private market. Currently, global banking industry worth $\$ 134$ trillion as the sector helps in intermediation, makes loans and provides credit. However, with the advent of blockchain, the game would not be as usual again as the digital currency promises high level of disruption in the traditional services of bankers: payment, fund raising, clearance and settlement systems, securities and loan.

What is the stake of traditional bankers in this regard? Is there anything to be afraid of? The traditional bankers have a lot of role to play to keep the momentum going if they don't want to be left behind. The role of bankers for instance, would be to allay 
the fears of adopters by employing their existing infrastructure to encourage acceptance in retail stores, allow bitcoin credit cards to use processing infrastructure while offering smartphone applications alongside online portals for the immediate exchange to and from fiat. This may seem scary or might be "suicidal attempt" for the bankers who may be feeling that their jobs are being taking over. However, experience has shown that many start-ups and some other big institutions are already investing their capital into these kinds of solutions. As at 2018, Bitcoin processes over $\$ 8$ Billion worth of transactions per day and would likely overtake MasterCard, the second biggest credit card in the world. This shows that the digital currency is a reality even though many are still very sceptical about it.

The banking and payment industry has become a tough terrain and to survive in this new era, the banks must not be inertia in their attitude; they must be innovative and be ready to quickly review their existing business model in order to know how to fit into the scheme of things. Since open banking is now inevitable and blockchain is presenting new opportunity, the banks in developing countries must be started to prepare now as the wave of change is blowing faster across the Atlantic Ocean.

\begin{tabular}{l} 
Your next submission with Juniper Publishers \\
will reach you the below assets \\
- Quality Editorial service \\
- Swift Peer Review \\
- Reprints availability \\
- E-prints Service \\
- Manuscript Podcast for convenient understanding \\
- Global attainment for your research \\
- Manuscript accessibility in different formats \\
( Pdf, E-pub, Full Text, Audio) \\
- Unceasing customer service \\
Track the below URL for one-step submission \\
https://juniperpublishers.com/online-submission.php \\
\hline
\end{tabular}

